\title{
BRINGING THE "TRICKSTER WASP" INTO THE DISCOURSE ON BIOTECHNOLOGICAL CONTROLS OF "PEST WASPS"
}

\section{O. Ripeka Mercier*}

\begin{abstract}
Last year the New Zealand Government's announcement of a "Predator Free NZ 2050" was accompanied by a target for a significant scientific breakthrough capable of eradicating at least one small mammalian predator by 2025. Strong responses and consolidation and repositioning activity ensued. A commonly agreed gap in our understanding is whether we, as a society, would allow the use of such a control, if it existed. Does a "social licence to operate" exist for the NZ scientific establishment? For the New Zealand Government, for that matter? The National Science Challenge funds a project that seeks to answer these questions, by exploring the "social and cultural" perceptions of biotechnological controls of German and common wasp populations. Here I present key considerations informing our framing and methodology for exploring this issue, including how Maamingidae, a native family of wasps, acts as a touchstone for considering what research into wasps adds to the broader discourse around pests.
\end{abstract}

\section{Keywords}

biotechnology, wasps, social and cultural perceptions, tikanga

* Ngāti Porou. Senior Lecturer, Te Kawa a Māui-School of Māori Studies, Victoria University of Wellington, New Zealand. Email: ocean.mercier@vuw.ac.nz

DOI: 10.20507/MAIJournal.2017.6.1.6 


\section{Māmingatia}

In 2001, John Early and colleagues published a biological description of "Maamingidae, a new family of proctotrupoid wasp" (Early, Masner, Naumann, \& Austin, 2001, p. 341) endemic to Aotearoa New Zealand. At 1-2 millimetres in length, the members of the family are a tenth of the size of both the Vespula vulgaris (common wasp) and the Vespula germanica (German wasp). Specimens of the wasp had been collected and catalogued by the Department of Scientific and Industrial Research in the 1970s, and it was first referred to as a "new family" in 1990 (Early et al., 2001, p. 344). Using their own field surveys, observations and previous studies related to the insect, Early and colleagues described in detail two distinct insects, and offered the names Maaminga marrisi and Maaminga rangi for them, unifying them into the family Maamingidae. "Māminga" variously means to beguile, to play pranks with, to pretend, to act mysteriously and with guile (Williams, 1971). "Maaminga is a Maori word, which can mean a 'trickster' and 'mystifying', referring to the puzzling combination of characteristics that made the initial, superfamily placement of this genus uncertain" (Early et al., 2001, p. 344). Early's co-researcher Austin (2001) explains elsewhere that "it appears to be a composite of two unrelated wasp groups, with the front end typical of one group and the back end of another". While, these proctotrupoids are by no means the only endemic species of wasp, the Maamingidae family represents a beguiling touchstone for a discussion about the issue of introduced wasps.

In any act of naming, humans project what they perceive as the characteristics and qualities on to the named. Although Early et al.'s paper does not explicitly name Maaminga marrisi and Maaminga rangi "trickster wasps", subsequent literature has played up this aspect (Austin, 2001; Early, 2007). "Trickster" is unlikely to be a good reflection on the nature of the wasp; nevertheless, the moniker appeals to us on several counts: the evasion of notice by virtue of its size, its apparent localisation in New Zealand, its preference for certain habitat types for unknown reasons and its evasion of categorisation by "pretending" to be other species. In Māori oral histories, Māui, the trickster demi-god, was able to achieve above and beyond his corporeal limitations as a human. Conveyed romanticism notwithstanding, the scientists' state of being "baffled", "puzzled" and "mystified" by the apparent similarity of some of Maamingidae's features to other wasps is more a reflection of the observer than the observed.

This consideration is crucial in reflecting on the discourse surrounding "pest wasps". It is true that stings from the common and German wasps are painful and can be life-threatening. However, amongst other things, wasps have been labelled "angry" (Hub, 2011), "bandits" (Hunt, 1996) and "ruthless villains, dangerous invaders" (Carson, 2016). This invites us to be similarly ruthless in our responses. For instance, we must wage a "war on wasps" (Victoria University of Wellington, 2016) and "just kill the bastards" (van Noort, 2016). This kind of vilification is not confined to wasps-the Listener headlined its response to PredatorFree NZ 2050 "Natural Born Killers" (MacFie, 2016). However, Steer (2016) counters that "these pathetic, phoney 'wars' are malicious, incompetent and uneducated and they need to stop". He goes on to state that "if you're searching around for the correct words to frame what we're doing, it's not 'battle' or 'fight' but rather 'extermination' or 'massacre'." Just as German wasps did not ask to be cast in the role of "invader" neither does the Maamingidae family take on itself the role of "trickster".

Steer (2016) goes on to suggest that the discussion be framed not as a war fought to eradicate any introduced species in order to rewind to a mythical Gondwanaian ecosystem, but as management for the environments of the future, using respect and kaitiakitanga. This is a good suggestion, but smacks of the melting pot 
debates that argue that we need to get over the notion of a bicultural nation, with all the attendant dismissal of Te Tiriti that that entails, and give way to a multicultural one. If we listen first to and prioritise the place of the metaphorical māminga, how differently do our discussions and activities evolve? Do we see a war, or even a series of battles? What is the place of pest control? What then the place of biotechnology?

\section{Kaitiakitanga}

Initiatives to establish pest-free islands and sanctuaries are widespread and long-standing, and countless hours of volunteer effort have been invested in them. As someone who lives in the suburb Te Kaha-o-ngā-Rore (Karori-place of many bird snares), I directly benefit from the now everyday sight or sound of tui, kākā, kereru and kākāriki in the trees around my house, there thanks to the predator-proof fence and ongoing protection and preservation efforts at Zealandia. However, the government, policy and human faces of these efforts have marginalised other concerns. Early sanctuaries exhibited “ecological colonialism”. For instance, Māori were removed from Little Barrier Island in the 1890s to instate a wildlife sanctuary (Muir, 1995). Government legislation without regard to customary take has also unfairly disadvantaged Māori, in some cases not just disrupting their access to native species used for kai, but removing their mātauranga from lived practice, intergenerational transmission and even collective memory (Waitangi Tribunal, 2011).

These criticisms notwithstanding, Māori have actively exercised their kaitiakitanga in multiple ways to restore balance to ecosystems. Mechanisms exist to partner with others to realise these goals, such as the Department of Conservation's (2015) Ngā Whenua Rāhui fund, which has supported numerous local projects for more than 25 years. More recently, with initial support from the Ministry of Business, Innovation and Employment, Te Tira
Whakamātaki-Māori Biosecurity Network was established, and it aims to "connect Māori organisations with researchers and provide a culturally safe place for Māori to discuss biosecurity issues of importance to them" (Bioprotection Research Centre, 2016). Its founders have stated that "raising awareness" and connecting people are key to building a healthy future for New Zealand's biological heritage" (Bioprotection Research Centre, 2016). As a part of the National Science Challenge's "Our Biological Heritage" theme, our research project into novel biotechnological tools for controlling wasp populations was launched. This will potentially contribute to the government's goal to develop "a scientific breakthrough capable of removing at least one small mammalian predator from New Zealand entirely” by 2025 (Joyce, Guy, \& Barry, 2016). But these controls cannot be implemented without a social licence to operate (SLO; Ruckstuhl, Thompson-Fawcett, \& McRae, 2014).

An SLO denotes community acceptance and permission for an organisation to practise. In New Zealand, "SLO" has entered the common vernacular in instances where people have become dissatisfied with operators in the oil, dairy and tourism industries, as the following recent examples illustrate:

Statoil knows that after such relentless local opposition, its social licence to operate in our country is tenuous. (Simcock, 2016)

The latest Public Perceptions of the NZ Environment report puts even more pressure on the dairy sector to earn a social licence to operate from the Kiwi public, according to Fish \& Game NZ. (Fish \& Game New Zealand, 2013)

The strong tourism sector has come to the rescue of an economy that might otherwise have been more severely knocked around by the dairy downturn, but many observers are now speaking of risks to the [Tourism] industry's “social licence to operate”. (MacFie, 2017) 
The SLO is an important principle for the discussion of using scientific tools in a way that the public accepts. Furthermore, the scientific community needs to engage with openness and in good faith to retain an SLO. Thus, key aspects of the project include reviewing documented perceptions, establishing how biotechnological controls are perceived now, and canvassing Māori perspectives in particular. Do scientists in fact have an SLO with Māori? A qualitative enquiry will use a blog site for the communication of information (maaminga. wordpress.com), interviews and wānanga. In addition, a separately funded quantitative study of perceptions of controls of both wasps and rats is under way, led by Landcare Research and the Department of Conservation (McDonald, 2017).

By contrast with Maamingidae, the German and common wasps, introduced in the 1940s and 1970s respectively, are now prolific in New Zealand. As well as their persistent presence in urban areas, they have taken up habitat in beech forest, particularly in the Nelson Lakes area. They consume honeydew deposited on beech trees by the scale insect, displacing native birds and insects from this food source. They have also reportedly attacked native bird chicks. The biomass of wasps in the Nelson Lakes area at least equals the biomass of birds, stoats and rodents combined. They have no natural predators in Aotearoa New Zealand. Traditional controls involve finding wasp nests and burning or lacing them with poison. In 2015 a less dangerous and time-intensive control was piloted by Merchento from Nelson. Vespex, a protein bait that includes fipronil (a broad-use insecticide), has since been shown particularly effective at neutralising wasp nests. Worker wasps treat the poison as a food, and carry it back to the nest. Furthermore, the first tests have shown the bait to be unattractive to bees (Lester et al., 2013).

However, a suite of biotechnological tools might enable controls to be more targeted, reducing collateral damage on other species. In our National Science Challenge project, four techniques are under consideration and exploration by co-researchers Max Suckling, Phil Lester, Dan Tompkins and Simon Fowler. They are:

1. Pheromones-in-trap lures, and for behavioural manipulation of wasps.

2. RNA interference-interruption of "messenger DNA" leading to non-expression of biological characteristics (e.g., fertility).

3. Trojan female-insert a queen into a nest to produce infertile males.

4. Trojan mite-wasp-dwelling mites carry and spread a pathogen into a nest.

The first three techniques are designed to disrupt the reproductive cycle. Scientists have been keen to distance RNAi or "gene silencing” from genetic modification. Space limitations restrict me from delving into the details more deeply here; a series of future articles will report on how these controls are perceived. The following advertisement was written to attract a $\mathrm{PhD}$ student to the project.

In Aotearoa New Zealand, Common and German wasps are having a notable impact on native flora and fauna and may impact on our ability to act as kaitiaki of the environment. As part of the National Science Challenges: Our Biological Heritage theme, a team of researchers are exploring novel biotechnological methods of controlling pest wasp populations (see http://www.victoria.ac.nz/ capital-thinking/wasps/buzz-off for more details). How does the wider Aotearoa community perceive these new controls? Are some of the tools more acceptable than others to use on pest wasps in Aotearoa? Under what conditions might we accept and use biotechnological controls? How can tikanga and mātauranga frame and contribute to this discourse? (Victoria University of Wellington, 2016)

While the above description frames wasps as a pest, we have been careful to allow room for 
the question of how notions of kaitiaki, tikanga and mātauranga can frame the discourse. We might also ask whether the discourse should be reframed from a non-human or more-thanhuman perspective (Galloway, 2017). What could a focus on Maamingidae bring to the discourse that our focus on native birds does not?

Unlike possums, rats and mustelids, then, the introduced wasp species have what we might call Indigenous cousins. Rat species have all been introduced, but not all at the same time. The kiore is a taonga species to some, even while not endemic to Aotearoa. If it came with the East Polynesian voyagers, could it be considered endemic now? Karaka is not endemic, but groves of karaka are considered an important part of Aotearoa's natural and social heritage.

Thus some of the questions that emanate from the enquiry are: As kaitiaki of Aotearoa's wao nui a Tāne whakapapa/biological diversity, how do and can we exercise kaitiakitanga? If we were to add some tools to our kete, what technologies, if any, can be considered consistent with tikanga? Finally, if tikanga is weighed up on a case-by-case scenario (Mead, 2003), what does it look like in the case of pest wasps? How might it look different in other pest populations?

\section{Tikanga}

We now turn very briefly to questions of tikanga under consideration when thinking about biotechnologies, tikanga and methodologies for the project. A survey of Māori perceptions of biotech is the subject of a separate review, so only selected literature is considered here.

Māori environmental students are coming to affectionately refer to a "trilogy" of key values related to te taiao: whakapapa, mauri and kaitiakitanga. The trilogy recognises all earthly inhabitants as interrelated through whakapapa, phenomenological powers (atua) energise domain inhabitants through mauri, and humans have distinct responsibilities to act as kaitiaki within and arguably for the system.
This trilogy may be attributable to the growing body of academic and grey literature (e.g., iwi management plans) that reifies these as key environmental values for Māori.

Many frameworks have been developed for Māori to identify and analyse their ethical standpoints on scientific advances (usually biotechnologies) and to assist in making decisions about these. For instance, Hirini Moko Mead's (2003) 5-Tests framework offers a series of tikanga-based considerations (tapu, mauri, take-utu-ea, precedents and principles) by which to assess "ngā ahi e ngiha mai nei" (p. 335). "The flames that flare up" is a metaphor for contentious issues that the modern world throws forth. The 5-Tests framework lays out what Mead believes are the most important considerations when establishing a "Māori" viewpoint on an issue. His use of the whakatauki "Taku ahi tūtata, taku mata kikoha, taku ahi mamao, taku mata kiporo (When the fire is close by, the point of the weapon is sharp, but when the fire is distant the point is blunt)" (Mead, 2003, p. 335) in this context is provocative. Without fire or contention, our weapons and tools become dull. Mead may be arguing that we need pressure from outside, lest our unique values and ways of living themselves become untested, dull and unused.

The mana wahine framework developed by Jessica Hutchings (2004) examines the role of colonial hegemony in sidelining Māori women's concerns and explicitly seeks to counter the effects of colonisation and claim "ethical space" in the debates regarding biotechnologies. She agrees with Mead that tikanga have to be a critical focus area (adding kaitiaki), but also considers other aspects: relationships (Papatūānuku, Te Tiriti o Waitangi) and autonomy (decolonisation, decision-making and intellectual property rights). This leads her to ask how the new technology will benefit Māori, Māori women and partners to Te Tiriti? Will Māori tino rangatiratanga be maintained and enhanced, or degraded? In addition, she recommends that "a mana wahine analysis be 
applied to the deconstruction of western science and knowledge to provide further understanding of the assumptions, power and systems that they privilege" (Hutchings, 2004, p. 24).

Mahina-a-Rangi Baker (2011, 2012) interviewed elders in the ART (Atiawa-ToaRangatira) confederacy about their mātauranga related to ngārara. Through analysing the kōrero, she devised the Korowai framework to highlight the five most important aspects of tikanga in relation to ngārara-mauri, whakapapa, tohu, tapu and kaitiakitanga-which allow the community to "get to the decisionmaking table with a comprehensive evidence based understanding of their people's position on a complex issue from which they can negotiate a decision" (Baker, 2012, p. 96). She draws upon the same interviews and the framework for an assessment rubric against genetic engineering. Ultimately, the Korowai framework “ensures we don't compromise those values for the sake of fulfilling inequitable and false notions of 'progress'” (Baker, 2012, p. 97). Timely reminders to remain vigilant against inequity and false progress aside, Baker's work on insects has obvious relevance for the study on wasps.

\section{Concluding Remarks}

In the first of this commentary's three sections, I introduced the Maamingidae wasp family. I pointed out that the very naming of the family is a projection of human qualities and perceptions upon the tiny and little-known native insect. Indeed, the term māmingatia, meaning beguiled or deceived, could equally describe some of the pest propaganda rolled out to the public.

"Phoney wars" notwithstanding and propaganda aside, our obligations as kaitiaki should guide us to protect native species by maintaining pest-free environments. Done right, pest-free "islands" (whether literal islands, or bounded sanctuaries) have been shown to support and display Indigenous biodiversity, lifting the wairua of tangata and whenua alike. Could the whole of Aotearoa become a pest-free island sanctuary off the coast of the world?

In the second section, I considered how kaitiakitanga obligations can be considered as evident in the different initiatives around so-called predators, and particularly biotechnological controls of pest wasps. Thirdly, I considered specific tikanga that can and will guide us in the inquiry into social and cultural perceptions of biotechnology. Given the cautions, under what conditions might we explore, accept, pilot and allow the use of biotechnological controls?

This discussion will ultimately lead us to the question of how generalisable the potential use of wasp-specific biotechnological controls to other pests is. While it is inaccurate at least to paint wasps as "ruthless villains ... starting an army in foreign territory" (Carson, 2016), it is easier to justify this kind of language with wasps than with more cuddly or cute creatures, such as possums, rats, stoats and hedgehogs. There are many voices to be mindful of in this debatewhether they are new, attention-grabbing and strident, like Vespula germanica, or ancient, small and unobtrusive, like Maaminga rangi. If we consciously listen for the voice of the "trickster wasp", it might help us take careful and considered steps into the future.

\section{Glossary}

$\begin{array}{ll}\text { atua } & \begin{array}{c}\text { god, domain power and } \\ \text { authority } \\ \text { iwi }\end{array} \\ \text { place-specific tribe } \\ \text { kai } & \text { food, meal } \\ \text { kaitiaki(tanga) } & \text { guardian(ship) } \\ \text { kākā } & \text { New Zealand parrot, } \\ & \text { Nestor meridionalis } \\ & \text { septentrionalis } \\ \text { kākāriki } & \text { New Zealand red- } \\ & \text { crowned parakeet, } \\ & \text { Cyanoramphus } \\ & \text { novaezelandiae }\end{array}$




\begin{tabular}{|c|c|}
\hline karaka & $\begin{array}{l}\text { New Zealand laurel tree, } \\
\text { Corynocarpus laevigatus }\end{array}$ \\
\hline \multirow{3}{*}{$\begin{array}{l}\text { kereru (kuku, } \\
\text { kukupa) }\end{array}$} & New Zealand (wood) \\
\hline & pigeon, Hemiphaga \\
\hline & novaeseelandiae \\
\hline kete & basket, kit \\
\hline kiore & Pacific rat, Rattus exulans \\
\hline kōrero & $\begin{array}{l}\text { conversation, speech, } \\
\text { discourse }\end{array}$ \\
\hline māmingatia & beguiled or deceived \\
\hline mātauranga & knowledge, ways of \\
\hline & knowing \\
\hline mauri & energy, life force \\
\hline ngārara & insect, reptile \\
\hline Papatūānuku & Mother Earth \\
\hline taiao & environment \\
\hline take-utu-ea & process of compromising \\
\hline & to resolve an issue \\
\hline tangata & person, people \\
\hline taonga & treasure, resource \\
\hline tapu & sacred, state of restriction \\
\hline Te Tiriti & the Treaty (of Waitangi) \\
\hline tikanga & protocols \\
\hline tino rangatiratanga & self-determination, \\
\hline & autonomy, \\
\hline & self-government \\
\hline tohu & sign, omen \\
\hline tui (tūī) & Parson bird, \\
\hline & Prosthemadera \\
\hline & novaeseelandiae \\
\hline wairua & spirit, soul \\
\hline wānanga & Māori houses of higher \\
\hline & $\begin{array}{l}\text { learning, seminar, } \\
\text { discussion }\end{array}$ \\
\hline wao nui a Tāne & forest domain \\
\hline whakapapa & genealogy, folk taxonomy \\
\hline whakatauki & proverb \\
\hline whenua & land \\
\hline
\end{tabular}

\section{References}

Austin, A. (2001, July 2). Tiny trickster flies into the zoological books. Retrieved from https://www. adelaide.edu.au/news/news244.html

Baker, M. (2011). The Korowai framework: Assessing GE through the values the ART Confederation associates with ngārara (Unpublished master's thesis). Victoria University of Wellington, New Zealand.

Baker, M. (2012). The Korowai framework: Assessing GE through tribal values. New Genetics and Society, 31(1), 87-98. http://doi.org/cgj2n3

Bioprotection Research Centre. (2016). Māori focus for new biosecurity network. Retrieved from http:// bioprotection.org.nz/news/m\% C4\% 81 orifocus-new-biosecurity-network

Carson, J. (2016, December 30). Ruthless villains, dangerous invaders: A history of German wasps in New Zealand. Stuff. Retrieved from http:// www.stuff.co.nz

Department of Conservation. (2015, March 11). Ngā Whenua Rāhui celebrates 25 years. Retrieved from http://www.doc.govt.nz/news/stories/2015/ march/nga-whenua-rahui-celebrates-25-years

Early, J. W. (2007, September 24). Wasps and beesparasitic wasps. In Te Ara-The Encyclopedia of New Zealand. Retrieved from http:// www.teara.govt.nz/mi/photograph/11147/ maaminga-marrisi

Early, J. W., Masner, L., Naumann, I. D., \& Austin, A. D. (2001). Maamingidae, a new family of proctotrupoid wasp (Insecta: Hymenoptera) from New Zealand. Invertebrate Taxonomy, 15(3), 341-352. http://doi.org/cx6qsk

Fish \& Game New Zealand. (2013, December 13). Dairy desperately needs social licence to operate. Scoop. Retrieved from http://www.scoop.co.nz

Galloway, A. (2017). What we do. Retrieved from http://morethanhumanlab.org/what-we-do

Hub, S. L. (2011). Angry wasp versus hungry ant. Retrieved from https://beta.sciencelearn.org.nz/ resources/1196-angry-wasp-versus-hungry-ant

Hunt, R. (Producer and Director). (1996). Bandits of the beech forest [Television documentary]. New Zealand: NZOnScreen.

Hutchings, J. (2004). Claiming our ethical space: A mana wahine conceptual framework for discussing genetic modification. He Pukenga Korero, $8(1), 17-25$.

Joyce, S., Guy, N., \& Barry, M. (2016). Predator free 2050 to be a massive team effort. Retrieved 
from https://www.beehive.govt.nz/release/ predator-free-nz-2050-be-massive-team-effort

Lester, P. J., Beggs, J. R., Brown, R. L., Edwards, E. D., Groenteman, R., Toft, R. J., \& Ward, D. F. (2013). The outlook for control of New Zealand's most abundant, widespread and damaging invertebrate pests: social wasps. New Zealand Science Review, 70(4), 56-62.

MacFie, R. (2016, November 26). Natural born killers. New Zealand Listener, pp. 16-23.

MacFie, R. (2017, January 14). Peak paradise. New Zealand Listener, pp. 16-25.

McDonald, E. (2017, May). If we build it, will they use it? Exploring New Zealanders' social licence towards novel pest control methodologies. Paper presented at the Crazy \& Ambitious Conference: New Zealand's Biological Heritage, Te Papa Tongarewa, Wellington, New Zealand.

Mead, H. M. (2003). Tikanga Māori. Wellington, New Zealand: Huia.

Muir, J. (1995). Ecological colonialism (Unpublished master's thesis). University of Waikato, Hamilton, New Zealand.

Ruckstuhl, K., Thompson-Fawcett, M., \& McRae, H. (2014). Māori and mining: Indigenous perspectives on reconceptualising and contextualising the social licence to operate. Impact Assessment and Project Appraisal, 32(4), 304-314. http:// doi.org/b7hj

Simcock, K. (2016, November 24). This is not a drill: Greenpeace calls for a summer of action [Web log post]. Retrieved from http://www.greenpeace. org/new-zealand/en/blog/this-is-not-a-drill/ blog/57755

Steer, J. (2016, August 8). A war on pests and weeds is "malicious" and "incompetent" and will ultimately fail. Stuff. Retrieved from http://www. stuff.co.nz

van Noort, T. (2016, January 13). Just kill the bastards [Web log post]. Retrieved from https://aucklandecology.com/2016/06/10/just-kill-the-bastards Victoria University of Wellington. (2016). War on wasps. Retrieved from http://www.victoria. ac.nz/capital-thinking/wasps

Waitangi Tribunal. (2011). Ko Aoteaora tenei: A report into claims concerning New Zealand Law and policy affecting Māori culture and identity. Wellington, New Zealand: Author.

Williams, H. W. (1971). Dictionary of the Maori language (7th ed.). Wellington, New Zealand: Legislation Direct. 